\title{
Western Ragweed Pollen IgG Measurement
}

National Cancer Institute

\section{Source}

National Cancer Institute. Western Ragweed Pollen IgG Measurement. NCI Thesaurus.

Code C130094.

A measurement of the western ragweed (Ambrosia psilostachya) pollen Ig G in a biological specimen. 